
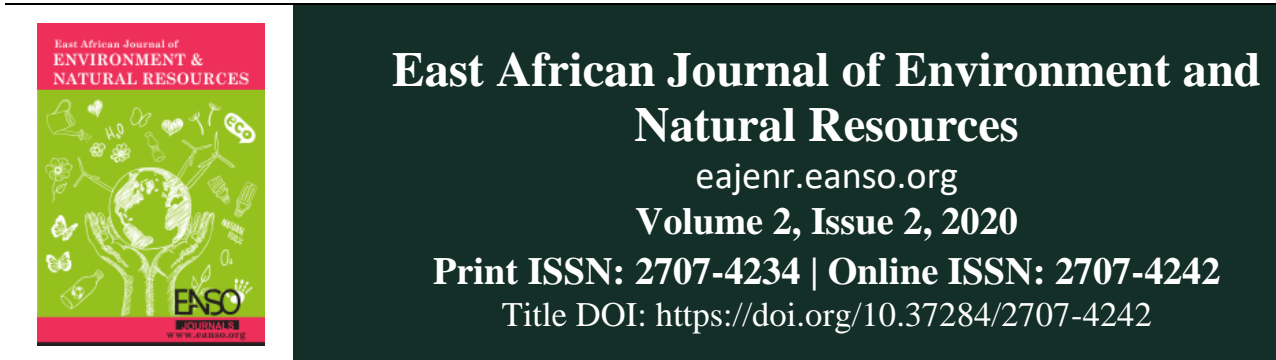

Original Article

\title{
Impacts of Farming Activities on the Conservation of Sondu River Basin in Kericho County, Kenya
}

\author{
Japhet Kipngeno ${ }^{1}$, Prof. Paul A. Omondi ${ }^{2} \&$ Dr. Abdirizak A. Nunow ${ }^{2}$ \\ ${ }^{1}$ University of Kabianga, P. O. Box 2030 - 20200, Kericho, Kenya. \\ ${ }^{2}$ Moi University P. O. Box 3900, Eldoret, Kenya. \\ *Author for Correspondence email: japhetkipngeno2013@gmali.com
}

Article DOI: https://doi.org/10.37284/eajenr.2.2.182

\section{Date Published: ABSTRACT}

14 July 2020 Governments and environmental conservationists agree that wetland resources need to be utilized sustainably to ensure the continued presence of wetlands and

Keywords: their ecological goods and services. Ideally, wetlands should be integrated into the national and local land use plans to ensure sustainable use and management of the

Wetlands, resources. However, this is not the case as far as Kenya is concerned. Instead, there Conservation,

Human Activities,

Sustainable

Utilization,

Planning and

Management. is rampant exploitation of wetlands by individuals, organizations and even government agencies with no regard for environmental conservation. Therefore, this study was undertaken to investigate the impact of human activities on wetland conservation with a focus on the Sondu River Basin. The objective of the study was to establish the farming activities on the Conservation of Sondu River Basin Kericho County, Kenya. The study was grounded on the integrated water resource management theory. This study adopted a concurrent triangulation research design, which entailed a combination of both qualitative and quantitative data. The target population for the study was 164 respondents in which a sample of 144 respondents was selected using Slovin's formula. The sample was randomly selected with the inclusion criterion being that the chosen respondents were homogeneously engaged in human activities that affected wetland conservation. Intensive data cleaning exercise was carried out including checking for outliers, missing data imputation and variable transformation. The collected data were analyzed by use of descriptive statistics such as frequencies, percentages and summation and presented in the form of tables and charts. The results of the study will inform policy and practice in the management and conservation of the Sondu River wetland area. The study established that human activities such as farming, logging, construction, drilling, building and construction and settlements have 
immensely hampered conservation of Sondu wetland. Further, it was noted that it is indeed possible to gain vital information about the human activities responsible for the degradation of wetlands.

\section{APA CITATION}

Kipngeno, J., Omondi, P., \& Nunow, A. (2020). Impacts of Farming Activities on the Conservation of Sondu River Basin in Kericho County, Kenya. East African Journal of Environment and Natural Resources, 2(2), 35-43. https://doi.org/10.37284/eajenr.2.2.182

\section{CHICAGO CITATION}

Kipngeno, Japhet, Paul Omondi, and Abdirizak Nunow. 2020. "Impacts of Farming Activities on the Conservation of Sondu River Basin in Kericho County, Kenya”. East African Journal of Environment and Natural Resources 2 (2), 35-43. https://doi.org/10.37284/eajenr.2.2.182.

\section{HARVARD CITATION}

Kipngeno, J., Omondi, P. and Nunow, A. (2020) "Impacts of Farming Activities on the Conservation of Sondu River Basin in Kericho County, Kenya", East African Journal of Environment and Natural Resources, 2(2), pp. 35-43. doi: 10.37284/eajenr.2.2.182.

\section{IEEE CITATION}

J. Kipngeno, P. Omondi, and A. Nunow, "Impacts of Farming Activities on the Conservation of Sondu River Basin in Kericho County, Kenya”, EAJENR, vol. 2, no. 2, pp. 35-43, Jul 2020.

\section{MLA CITATION}

Kipngeno, Japhet, Paul Omondi, and Abdirizak Nunow. "Impacts of Farming Activities on the Conservation of Sondu River Basin in Kericho County, Kenya". East African Journal of Environment and Natural Resources, Vol. 2, no. 2, Jul 2020, pp. 3543, doi:10.37284/eajenr.2.2.182.

\section{INTRODUCTION}

The conservation of wetlands has become a critical issue in contemporary society because the human population is growing exponentially, thus putting pressure on existing natural resources. Wetlands deliver practical benefits to plants, animals, humans, and the overall ecosystem or bio-diversity (Roy, Jane, \& Venema, 2011). Coastal and inland marshes, for example, is the upbringing, latent, and wintering environments for thousands of wandering birds, including duckies, geese, swans, shorebirds, herons, and other wading birds.

Wetlands are critical to the sufficiency of humans in the precinct of welfare activities of the communities living in the environment, which includes water sanitation, flow regulations and management of critical water resources, forest covers for management of carbon blueprint and management of conservations and water management. According to the Ramsar Convention International List, there are 1,952 wetlands, which cover a total surface area of 1.9 million $\mathrm{km}^{2}$ in the United States (Ramsar Convention Secretariat, 2010).
Given the ecological importance of wetlands and the growing threats to environmental conservation today, various concerns have been raised globally over the state of the environment. Rebelo et al. (2010) outlined both global and regional initiatives that have been deployed to save wetlands from human activities. Among these concerns and efforts were the Rio-de-Janeiro Conference (1992), the Kyoto Protocol of 1995 and the Copenhagen Climate Meeting of 2009, all of which underlined that global and regional climate changes are a threat to land resources on which human survival relies (Rebelo et al., 2010). The existence of wetlands is under threat due to alarming human infringement and it is estimated that more than $50 \%$ of the world's inland wetlands have been lost. Much of this loss of wetlands worldwide is attributed to agricultural activities. In a profound sense, it is estimated that the loss of 56-65\% of existing wetlands in Europe and North America, 27\% in Asia, 6\% in South America and $2 \%$ in Africa is due to agricultural activities (Day et al., 2003).

In the US, Bernhard et al. (2003) assert that agricultural practices are the major source of pollution for most rivers. This matter is related to rivers, lakes, streams and springs found in the 
wetlands, which have serious relations with the cause of poor farming practices resulting in pesticides, fertilizers and industrial and wastewater discharges. A study by Ausseil et al. (2008) managed to portray the real risks of losing wetlands as have been witnessed in New Zealand, which has lost $90.0 \%$ of wetland, where the nation had over 2.4 million hectares and now only 250,000 hectares remains

Ahidur (2016) inspected the influence of human activities on wetlands in India. He found that the use of chemical fertilizers and pesticides in the agricultural fields around the wetlands are the major causative factors of wetland degradation and subsequent water pollution. Other harmful human activities were found to be the construction of houses, roads, agricultural land, and overfishing, among others. Ahidur concluded that the area cover of wetlands is decreasing day by day due to human encroachment, pollution, overgrazing and invasion of species. Wetlands are not wastelands, but play a role in promoting cultural, economic, aesthetic, and spiritual roles. According to Ahidur (2016), wetlands are the world's most threatened habitats due to accelerated drainage, land reclamation, pollution, and over-exploitation of wetland species. He proposes that the classification of wetlands as wastelands should be avoided as wetlands play an important biological, cultural, economic, aesthetic, and spiritual role.

Wetland degradation and loss are attributed to natural factors mainly, human activities, such as agriculture, industrial development, urbanization, pollution, and human settlements. Frenken and Mharapara's (2002) research-based on the valuation of the effect of human activities on degradations in Nyaruzinga. Wetland in Bushenyi District, South Western Uganda found that water quality is the most affected pollution, which ends up contaminating the wetlands. Other major human activities that affect wetlands in Kenya pertain to the change in land use patterns normally associated with population and settlements in rural Kenya (Matano et al.,2015). Such a phenomenon has been attributed to the problem associated with the Mau forest complex since human settlements have been encouraged by the change of land use. The aftermath has been diminishing forest cover, erosions, decreased soil cultivation quality, loss of vegetation's and rivers and all in what can be described as ecological instability in the region

In Kenya, a study by Wawira (2012) singled out over-extraction of water using water pumps and encroachment of river banks for agricultural purposes as the main human activities contributing to disharmony between the community, biodiversity and the Ondiri wetland natural resources. It was concluded that the outcome of human activities has led to environmental degradation and the respondents concurred that the wetland could as well become extinct soon. Grazing and farming were the other human activities mentioned by respondents in the entire study area. Muchiri's findings concurred with those of Macharia et al. (2010) reporting that the natural resources around the rural landscape within developing countries provide a variety of economic and environmental security for the whole community.

\section{THEORETICAL FRAMEWORK}

\section{Integrated Water Resource Management Theory}

The study proposed to use the integrated water resources management theory propounded Al Radif (1999). The building block of this theory is sustainable wetland utilization through allocation, developing and maintaining water possessions in the context of community, monetary and ecological factors. This theory is also supported by the Global Water Partnership which supports and helps in the coordination of water, land, and related resources.

Similarly, Roy, Jane and Venema (2011) are of the view that this theory critical since it elevates participatory management of wetlands. The theory can create awareness and elevates the financial aspect of wetlands by defining wetlands as assets having financial form. Therefore, the benefit of this theory is its ability to portray integrated water resources management as a structured approach in the management of wetland resources to encourages sustainable exploitation of wetland.

Jeffrey and Gearey (2006) suggest a compromise between the uses of water resources to sustain society but also as an economic base; therefore, water should be used in such a way that it promotes 
the creation of wealth and at the same time be sustainable for other natural ecosystems. It has also been observed that the theory captures the imagination of researchers in relation to water and wetland management. The theory has been encouraged as the most justifiable theory to integrated divergent views of what constitutes sustainable use of wetlands and economic exploitation of the same. In conclusion, this theory is critical in relation to human activities and wetlands management based on the impression that water, biodiversity, and natural security necessitated sustainable exploitation of wetland resources that requires water diversity is related to a variety of interdisciplinary factors to work as a group.

This theory is connected to the current study in that it addresses the current environmental conservation of wetland, a case of the Sondu River. This theory Table 1: Distribution of the Sample Size postulates that efforts to conserve wetlands that have undergone degradation will require interdisciplinary and inter-sartorial coordination, which is essential for proper management (Roy, Jane, \&Venema, 2011). Therefore, this theory is pertinent to this study when looking at the objectives.

\section{RESEARCH METHODOLOGY}

The minimum sample size for residents was obtained usingSlovin's formula. Using the formula, the sample was 144 respondents who were randomly selected, where the study assumed that the chosen respondents were in one way or another engaged in human activities in wetland under study. The central theorem was used to select the sample population, as shown in Error! Reference source not found. below.

\begin{tabular}{lll}
\hline Target group & Target Population & Sample \\
\hline Environmental Officers (NEMA) & 4 & 4 \\
County government officers & 10 & 10 \\
Social facilities (schools and church) & 20 & 20 \\
Local leaders (Administrative and Political) & 30 & 30 \\
Business people (Sondu Market) & 50 & 40 \\
Community members & 50 & 40 \\
Total & $\mathbf{1 6 4}$ & $\mathbf{1 4 4}$ \\
\hline
\end{tabular}

\section{DISCUSSION OF RESEARCH FINDINGS}

Out of a total of 144 questionnaires that were given out, 111 were filled and returned which comprised of six (6) cohort as provided in Table 2.

Table 2: Distribution of Response Rate

\begin{tabular}{llll}
\hline Cohort & Sample & Response & Achieved Return Rate \\
\hline Environmental Officers (NEMA) & 4 & 3 & $75.0 \%$ \\
County government officers & 10 & 8 & $80.0 \%$ \\
Social facilities (schools and churches) & 20 & 15 & $75.0 \%$ \\
Local leaders (Administrative and Political) & 30 & 25 & $83.0 \%$ \\
Business people (Sondu Market) & 40 & 30 & $75.0 \%$ \\
Community members & 40 & 30 & $75.0 \%$ \\
Total & $\mathbf{1 4 4}$ & $\mathbf{1 1 1}$ & $\mathbf{7 7 . 0 \%}$ \\
\hline
\end{tabular}

Demographic information of respondents consisted of gender, age, education, occupation, locality, and occupation. The necessity of such information was to confirm whether the research assessed the targeted 
East African Journal of Environment and Natural Resources, Volume 2, Issue 2, 2020

Article DOI: https://doi.org/10.37284/eajenr.2.2.182

audience and whether it captured the information which was being sought. The six provided the study analysis of the respondents 'demographic evidence.

Table 3: Respondents Demographic Information

\begin{tabular}{llll}
\hline Demographic Information & & Frequency & Percentage \\
\hline Gender & Male & 67.0 & 60.0 \\
& Female & 44.0 & 40.0 \\
& Total & 111 & 100.0 \\
\hline Age & Less than 18 & 11.0 & 10.0 \\
& $18-35$ & 22.0 & 20.0 \\
& $36-50$ & 34.0 & 30.0 \\
& $>51$ & 44.0 & 40.0 \\
& Total & 111 & 100.0 \\
\hline Highest Education Attained by Respondents & Primary & 11.0 & 10.0 \\
& Secondary & 22.0 & 20.0 \\
& Diploma & 38.0 & 34.0 \\
& Bachelor & 29.0 & 26.0 \\
& Others & 11.0 & 10.0 \\
& Total & 111 & 100.0 \\
\hline Duration of Residency in Sondu Area and Locality & <than 1 Year & 6.0 & 5.0 \\
& 1-5 Years & 11.0 & 10.0 \\
& 6-10 Years & 66.0 & 60.0 \\
& 10 Years & 28.0 & 25.0 \\
& Total & 111 & 100.0 \\
& Agriculture & 67.0 & 60.0 \\
& Business & 11.0 & 10.0 \\
\hline Occupation & Civil Servants & 22.0 & 20.0 \\
& Others & 11.0 & 10.0 \\
& Total & 111 & 100.0 \\
\hline
\end{tabular}

The gender of respondents indicated that most of the study participants are of male gender accounting for $60.0 \%$ as opposed to females at $40.0 \%$. Based on the magnitudes of male versus the female in the six (6) cohorts, the study recognized that the age dissemination of the respondents reached from less than 18 years to above 51 years of age. The majority (70.0\%) of the respondents who contributed in the study were found to be aged between 36-50 years (30.0\%) to those above 51 years $(40.0 \%)$ while those in the minority were in the age bracket of below 18 years as well those of 18-35 years of age.

Many of the study applicants had attained education level of Diploma at (34.0\%) followed by those who had attained Bachelor's degrees at $26.0 \%$, while the least was primary school leavers $(10.0 \%)$. The findings show that the largest cross-section of respondents has the ability to comprehend concepts presented to them as respondents in the study.

It was found that the majority (85.0\%) of respondents had been residents of the study area for 6-10 years, with the minority being resident for less than one year. The study found that most residents' occupation is in agriculture, accounting for $60.0 \%$, followed by civil servants accounting (20.0\%) such as Environmental officers (NEMA) and County government officers; the least number of participants were business people. The overall analysis of the data shows that the analysis utilized respondents who were qualified to provide well informative information about the subjects of the study. 
East African Journal of Environment and Natural Resources, Volume 2, Issue 2, 2020

Article DOI: https://doi.org/10.37284/eajenr.2.2.182

\section{Impact of Farming Activities on Sondu River Basin}

The second objective of the study was to establish the effects of human settlements on the conservation of the Sondu River Basin. The Findings are as shown in Table 4.

Table 4: Impact of farming activities on the Sondu river basin

\begin{tabular}{llll}
\hline & \multicolumn{1}{c}{ Acres } & F & \% \\
\hline Cultivated area (acres) & 1 Acres & 56 & 50.0 \\
& 0.75 Acres & 28 & 25.0 \\
& 0.5 Acres & 22 & 20.0 \\
& 0.25 Acres & 11 & 15.0 \\
\hline Times stayed in the wetland (Years) & $1-5$ Years & 56 & 50.0 \\
& 6-10 Years & 22 & 20.0 \\
& $11-15$ Years & 11 & 10.0 \\
& Over 15 Years & 22 & 20.0 \\
\hline Duration of cultivation of wetland & Permanently & 11 & 10.0 \\
& Temporary & 22 & 20.0 \\
Crops grown in Sondu river basin & Sometimes & 78 & 70.0 \\
& Maize & 39 & 35.0 \\
& Tomatoes/vegetables & 33 & 30.0 \\
Methods of draining excess water & Potatoes & 17 & 15.0 \\
& Legumes & 22 & 20.0 \\
& Digging Trenches & 39 & 35.0 \\
Use of fertilizers & Pumping & 33 & 30.0 \\
& Scaffolding & 39 & 35.0 \\
& Yes & 89 & 80.0 \\
& No & 22 & 20.0 \\
\hline
\end{tabular}

Cultivation in the study area was observed to be the leading activity recording (38\%)with most respondents owning $1 / 4$ acre of cultivated area $(60 \%)$ and most of them using it for the last 610years(40\%). Extensive maize and vegetable cultivation is predominant among cultivators in the wetland with $15 \%$ and $70 \%$, respectively. However, it should be noted that the unreliability of rainfall (91\%) was an important factor associated with the choice for wetland cultivation, especially during the dry period. Draining of water for ease of cultivation was done with the majority of the respondents digging trenches to drain excess water (85\%). However, those who cultivated either used chemicals or fertilizers on their fields $(80 \%$ and $60 \%$, respectively). According to Masala (2014), invasive species or non-native affect the native species by spreading wider and in abundance taking space for the latter. In spite of all the effects of humans on habitats, there is some positive contribution of human towards wetlands which includes restoring damaged riparian and wetlands ecosystem; other include limiting the use of fertilizers and pesticides, planting native species and conserving water.

\section{Influence of Farming Activities in Sondu River Basin}

The research sought to establish the effects of farming activities in Sondu Conservation. This was analyzed Using a Likert scale of 1-5 as shown, where 5=Strongly Agree, 4=Agree, 3= Undecided, 2=Disagree, and 1=Strongly Disagree. The findings are presented based on the research questions. The Findings are as shown in Table 5. 
Table 5: Farming Activities in Sondu River Basin

\begin{tabular}{|c|c|c|c|c|c|c|c|c|c|c|}
\hline & \multicolumn{2}{|c|}{$\begin{array}{l}\text { Strongly } \\
\text { Agree }\end{array}$} & \multicolumn{2}{|c|}{ Agree } & \multicolumn{2}{|c|}{ Neutral } & \multicolumn{2}{|c|}{ Disagree } & \multicolumn{2}{|c|}{$\begin{array}{l}\text { Strongly } \\
\text { Disagree }\end{array}$} \\
\hline & $F$ & $\%$ & $F$ & $\%$ & $\mathrm{~F}$ & $\%$ & $F$ & $\%$ & $F$ & $\%$ \\
\hline $\begin{array}{l}\text { Farming activities affect Sondu river } \\
\text { conservation }\end{array}$ & 40 & 44.0 & 22 & 20.0 & 11 & 10.0 & 22 & 20.0 & 11 & 10.0 \\
\hline $\begin{array}{l}\text { Land reclamation led to rapid soil } \\
\text { erosion }\end{array}$ & 69 & 62.0 & 20 & 18.0 & 11 & 10.0 & 6 & 5.0 & 6 & 5.0 \\
\hline $\begin{array}{l}\text { Soil preparation affects Sondu river } \\
\text { conservation }\end{array}$ & 61 & 55.0 & 28 & 25.0 & 11 & 10.0 & 6 & 5.0 & 6 & 5.0 \\
\hline $\begin{array}{l}\text { The cultivation methods do not support } \\
\text { river conservation. }\end{array}$ & 22 & 20.0 & 22 & 20.0 & 22 & 20.0 & 22 & 20.0 & 22 & 20.0 \\
\hline $\begin{array}{l}\text { Irrigation schemes applied here are not } \\
\text { the best for Sondu river conservation }\end{array}$ & 26 & 23.0 & 22 & 20.0 & 19 & 17.0 & 20 & 18.0 & 24 & 22.0 \\
\hline
\end{tabular}

Table 5 shows that the widely held opinion of respondents $60 \%$ either strongly agreed or agreed that farming activities affect Sondu river conservation. One of the chief ways in which people have been using the valley bottom swamp or lake marsh is cultivation. The study found that 80 $\%$ of respondents indicated that reclamation has led to quick soil erosion and hence damage to land covers in this region. Matsa and Muringaniza (2011) also noted that conflict and intense competitor exists amongst dissimilar categories of wetlands users whose maintenance rests on access to wetlands.

Concerning whether soil preparation affects Sondu river conservation, most of the respondents believed that soil preparation has a significant impact on Sondu Conservation. This makes the sustainability of the exploitation of wetlands resources to be very difficult; this is the root cause of conflicts between upstream and downstream farmers. The challenges of wetlands exploitation are further compounded by the fact that poor people live within a biomass-based subsistence economy and so their interest to take care of wetlands is shorter rather than long term measures.

The study also established that most cultivation methods do not support river conservation, as explained by $70.0 \%$ of the respondents. Bloom (1981) that wetlands are adversely affected by the removal of plant biomass. This is related to changes to vegetation and plant species and its dynamics and species composition. It has been noted that the country's wetlands have been mainly degraded by drainage, land reclamations, over-grazing, and eutrophication of inland waters because of agricultural pollution. Poverty has also been noted to be associated with negative farming practices, which make the sustainability of land to be extremely difficult and frustrating. Therefore, poverty is a major factor that affects the sustainable use of wetlands. Concerning whether Irrigation schemes applied were not the best for Sondu river conservation, $56 \%$ of the respondents agreed that the practices were unsuitable.

\section{Land Sizes Cultivated in Study Area}

\section{Figure 1: Land Sizes Cultivated in the Study} Area

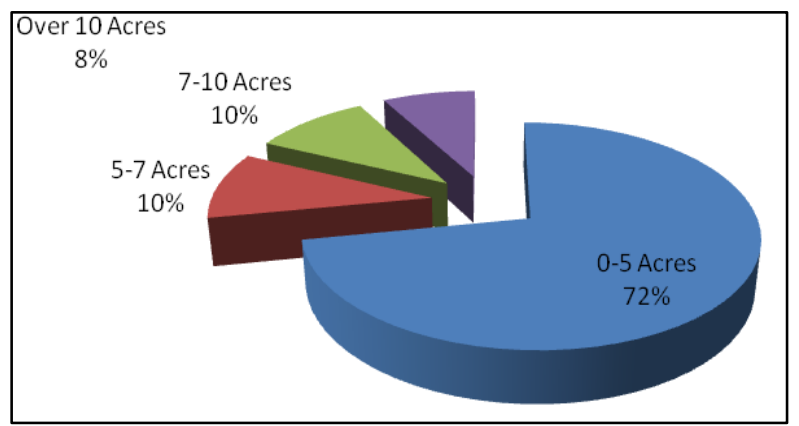

The results of the study show that most of the people who are farming inside the Sondu basin were small parcels of land ranging from 0-5 acres who account for $72 \%$, which is followed by $10 \%$ for land ranging between 5-7 acres with a similar proportion of 7 to 10 acres. This implies that most of the respondents had small parcels of land and that erratic farmers come once in a while to 
cultivate and only a few are permanent and regular farmers.

\section{Figure 2: Expansion of Farming Activities}

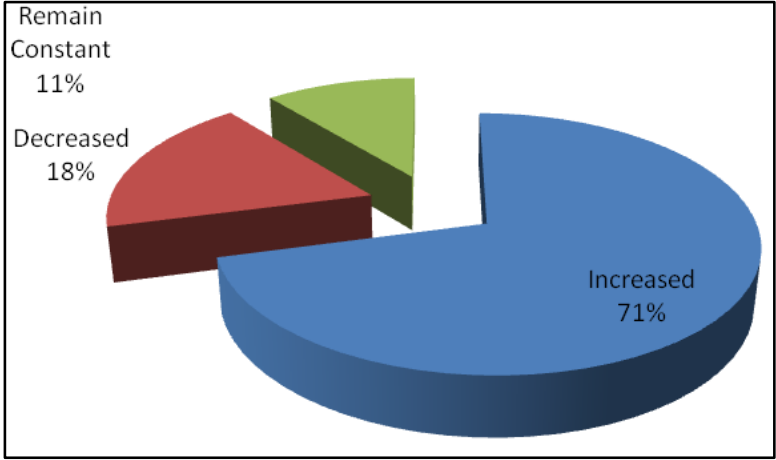

The research sought to establish the opinion of respondents on whether farming activities have increased or decreased or have remained constant. Table 6: Farming Activities on the Conservation
The study found that $71.0 \%$ of the respondents indicated that farming activities increased, $18.0 \%$ said farming activities decreased while $11.0 \%$ said farming activities remained constant.

\section{Effects of Farming Activities on the Conservation of Sondu River Basin}

Inferential statistics incorporated Pearson correlation, which involves testing the degree of relationship between human settlements and wetland conservation in Sondu River Basin's impact on the destruction of the conservation in terms of ecosystem, plants, and climate change. And the impact on conservation measured by indicators; destruction of the conservation in terms of ecosystem, plants, and climate change. The Findings are as shown in Table 6.

\begin{tabular}{lll}
\hline Correlations & & \\
& 1 & \\
\hline Conservation Effort & 1 & \\
& $\mathrm{~N}=111$ & \\
\hline Farming Activities & $.720^{* *}$ & 1 \\
\hline
\end{tabular}

The findings in the study show that there is a robust inverse correlation at 0.720 between farming activities and conservation of the Sondu River Basin which means that the effects of the removal of plant biomass.

\section{CONCLUSION AND RECOMMENDATION}

The study sought to find out the influence of human settlement activities in Sondu Conservation. The majority of the respondents agreed that human settlements pose a threat to Sondu River Conservation which could lead to ills like environmental degradation. Concerning the effects of alteration to Sondu River Conservation, most respondents agreed that, indeed, this issue leads to depletion of natural resources. The findings in the study show that there is a strong inverse correlation between human settlement and conservation of the Sondu River Basin, which means that the more people settle and create habitats in the vicinity of the Sondu River Basin, the more the destruction of the basin increases.

\section{REFERENCE}

Ahidur, R. (2016). Impact of Human Activities on Wetland: A Case Study from Bongaigaon District, Assam, India. International Journal of Current Microbiology and Applied Sciences, 5(3), 392-396.

Al Radif, A. (1999). Integrated water resources management (IWRM): an approach to face the challenges of the next century and to avert future crises. Desalination, 124(1-3), 145-153.

Ausseil, A. G., Gerbeaux, P., Chadderton, W. L., Stephens, T., Brown, D., \& Leathwick, J. (2008). Wetland ecosystems of national importance for biodiversity: criteria, methods and candidate list of nationally important inland wetlands. Landcare Research Contract Report LC0708/158.

Bernhardt, E. S., Likens, G. E., Buso, D. C., \& Driscoll, C. T. (2003). In-stream uptake dampens effects of major forest disturbance on watershed nitrogen export. Proceedings of the 
National Academy of Sciences, 100(18), 10304-10308.

Binkley, D. (1984). Ion exchange resin bags: factors affecting estimates of nitrogen availability. Soil Science Society of America Journal, 48(5), 1181-1184.

Bloom, P. R. (1981). Phosphorus adsorption by an aluminum-peat complex. Soil Science Society of America Journal, 45(2), 267-272.

Frenken, K., \&Mharapara, I. (2002). Wetland development and management in SADC countries. In FAO/SADC Sub-Regional Consultation, Harare (Zimbabwe), 19-23 November 2001. FAO.

Jeffrey, P., \&Gearey, M. (2006). Integrated water resources management: lost on the road from ambition to realisation? Water science and technology, 53(1), 1-8.

Macharia, J. M., Thenya, T., \&Ndiritu, G. G. (2010). Management of highland wetlands in central Kenya: The importance of community education, awareness and eco-tourism in biodiversity conservation. Biodiversity, 11(12), 85-90.

MacKay, H., Finlayson, C. M., Fernandez-Prieto, D., Davidson, N., Pritchard, D., \& Rebelo, L. M. (2009). The role of Earth Observation (EO) technologies in supporting implementation of the Ramsar Convention on Wetlands. Journal of environmental management, 90(7), 22342242.

Masala, H. (2014). Livestock populations and the household economy: A case study from southern Zimbabwe. Doctoral Thesis. University of London

Matano, A. S., Kanangire, C. K., Anyona, D. N., Abuom, P. O., Gelder, F. B., Dida, G. O., ... \&Ofulla, A. V. (2015). Effects of land-use change on land degradation reflected by soil properties along Mara River, Kenya and Tanzania. Open Journal of Soil Science, 5(01), 20.

Matsa, M., \&Muringaniza, K. (2011). An assessment of the land use and land cover changes in Shurugwi district

Zimbabwe. Ethiopian Journal of

Environmental Studies and Management, 4(1).

Ramsar Convention Secretariat. (2010), Inventory, Assessment, and Monitoring: An Integrated Framework for Wetland Inventory, Assessment, and Monitoring. Ramsar handbooks for the wise use of wetlands, 4th edition, vol. 13.

Rebelo, L. M., McCartney, M. P., \& Finlayson, C. M. (2010). Wetlands of Sub-Saharan Africa: distribution and contribution of agriculture to livelihoods. Wetlands Ecology and Management, 18(5), 557-572.

Roy, D., Barr, J., \&Venema, H. D. (2011). Ecosystem approaches in integrated water resources management (IWRM): a review of transboundary basins. International Institute for Sustainable Development \& International Institute for Sustainable Development.

Wawira, M. (2012). Headteachers' characteristics influencing instructional supervision in public primary schools in Kasarani Division. Unpublished Master's thesis, University of Nairobi, Nairobi. 